\title{
Secularizing Effects of Christian Mission: Fifty Years After Elmer Miller's “The Christian Missionary, Agent of Secularization"
}

\author{
Maryse Kruithof \\ Vrije Universiteit Amsterdam, Amsterdam, The Netherlands \\ kruithof@euc.eur.nl
}

\begin{abstract}
It has been suggested that Christianity is inextricably linked with secularization due to its emphasis on purification and rationalization. But if we believe secularization in Europe is at least partly caused by internal developments within Christianity, may we then assume that secularization emerges wherever Christian missionaries are successful? Has the Christian mission unwittingly instigated secularization in its mission fields? This literature review analyses the argument that American anthropologist Elmer Miller made in the article "The Christian Missionary, Agent of Secularization" (1970) and explores whether his thesis has been confirmed in academic literature during the past fifty years. Miller presents rationalization as the primary driver of secularization and explains how missionaries have played a decisive role in this process. This paper demonstrates that while rationalization has often been mentioned as an effect of the Christian mission in other sources, the process has rarely been linked to secularization in the mission field.
\end{abstract}

\section{Keywords}

secularization - rationalization - modernisation - westernization - diabolisation re-enchantment

\section{1 \\ Mission and Secularization}

Various authors have suggested that Christianity and secularization are inextricably linked. In the comprehensive study A secular Age (2007), Charles Taylor 
picks up Weber's classical thesis that secularization in Europe is the result of a long history of reform movements within western Christianity. An aim of these reform movements was to purify Christian beliefs and practices from folklore superstitions and a more widespread adherence to high standards of Christian piety and morality. In other words, "to get people to become better Christians" (Warner et al 2013: 16). However, some have suggested that this repeated emphasis on the purification of Christian thought and behavior took an antireligious turn during the European Enlightenment (Warner et al 2013: 16). The pursuit of rational and naturalistic explanations gradually displaced beliefs that refer to supernatural agency. Eventually, the Protestant focus on distinguishing the natural from the supernatural made it possible for believers to live entirely in the natural world (Taylor 2010: 304). In addition, the demand for sincerity, especially in Protestantism, stimulated the idea that individual choice was crucial. However, the possibility of choice also presented the option to reject the Christian faith, which made it possible to think of religiosity as optional. As such, the religious worldview was undermined and lost its plausibility at the societal level in part of the West, which invigorated a similar decline at the individual level. Eventually, more and more individuals simply stopped being religious (Tschannen 1991: 41).

During the heyday of European colonialism, western missionaries eagerly expanded their activities to new frontiers to spread their beliefs to all corners of the world. But if we assume that secularization in Europe was at least partly caused by internal developments within Christianity, we may expect it to emerge wherever missionaries propagate(d) their Christian teachings (Taylor 2007). Rational thinking, individual choice, and disciplined conduct define Anglo-Saxon revivalist evangelism, and were instrumental in the approach of western evangelical missionaries all around the world after the eighteenth century (Paas 2019). Yet these precise elements have also been acknowledged as important drivers of secularization. This raises the question of whether Protestant missions have played a significant role in clearing the way for secularization in non-western societies. The aim of this literature review is to examine academic literature on the nineteenth- and early-twentieth-century global missionary endeavour that explored the following question: "Has the Protestant mission unwittingly instigated secularization in its mission fields?"

This research project is made possible by the Dutch mission organization the GZ B (the Reformed Mission League). Their missionaries notice that while many mission churches are successful in attracting new members, they can simultaneously suffer from a 'backdoor dynamic,' resulting in significant losses of membership. They observe that their methods are vulnerable to individualism and rationalization, and that this has the potential to backfire. The GZB 
thus wondered whether there could be a correlation between their approach to missionizing and secularization and thus initiated this project to learn more about the long-term effects of the Protestant mission. The objectives of the project are thus not merely academic, as the research question is also an urgent one for mission organizations in the 21st century since more insight into the relationship between mission and secularization in the past could be useful for missionaries working in the field today.

The starting point of this literature review is the article "The Christian Missionary, Agent of Secularization" (1970) by American anthropologist Elmer Miller, published exactly fifty years ago. Miller, a former missionary, answers this question in the affirmative. He argues that missionaries should not be seen as conveyers of a supernatural worldview but instead as prime agents of secularization. The relationship continues to be a source of concern for missionaries (Paas 2019). The aim of this review is therefore to find out whether the thesis has been confirmed in academic literature since Miller's publication.

Clearly, in these discussions much depends on what counts as secularization. Countless chapters and articles have been written on how to define and measure secularization. The concept has been used to describe numerous processes, ranging from a decline in religiosity, to the decrease in social prestige and authority of religion, or to the emancipation of various societal spheres such as the arts, politics, economy, science, etc. from the religious sphere. In this review, I will use Miller's own definition, since this also aligns with the GZB's understanding of the concept. To him, secularization primarily implies rationalization. He explains how in a secularized society, day-to-day experiences are explained with scientific notions and people's attitudes concerning disease, accidents, death, and even cosmology mostly reflect naturalistic instead of supernaturalistic beliefs (Miller 1970: 14). Of the three elements previously mentioned - rational thinking, individual choice, and disciplined conduct - he concentrates on rational thinking only in explaining the missionary's influence in the mission field.

This literature review presents an overview of scholarly studies that further explore Miller's thesis. They provide examples from Protestant missions in different parts of the world, including Africa, the Middle East, Latin America, Asia, and the Pacific in the nineteenth and early twentieth century. The paper is divided in four parts. Part one discusses Miller's argumentation and examples. Part two presents research that followed in his footsteps and made similar claims for other mission fields. These studies confirm that the presence of western missionaries contributed to rationalization, but none of them explicitly claim a direct causal relationship between mission and secularization. Part three nuances the arguments that have been outlined in the first two parts and 
discusses various counter arguments to the thesis. In part four I will reflect on the main findings of this literature review.

\section{Missionaries: Agents of Secularization}

In his article "The Christian Missionary, Agent of Secularization" (1970), Elmer Miller argues that western missionaries instigated secularization in other parts of the world first and foremost because they were agents of westernization. He portrays the missionary enterprise as an instrumental part of western cultural imperialism: “... mission ideology reflects and even legitimates many of the values being forced at the same time upon the folk society by a colonial administration or a national government" (1970: 22). He continues to explain that the West had become a largely secular society in which the influence of the supernatural had progressively been circumvented (1970: 14; 23). Western missionaries did not know any other approach than to look at science for explanations for everyday experiences, and they conveyed this naturalistic worldview in their daily exchanges with local peoples. Miller's argument revolves entirely around the rationalizing effect missionaries had on the minds of the local population. Moreover, his thesis and argument are universalistic: he claims that the work of western missionaries active anywhere in the non-western world has led to secularization. His argument, however, is based on just one case: the work of two British Protestant mission organisations among the Toba in Northern Argentina between 1934 and 1955. Miller, once himself a Mennonite missionary among the Toba, returned to this field to conduct his anthropological research in the 196o's.

The main strategies of the Emmanuel and Mennonite missionaries were preaching, providing education and healthcare, and boosting local economic development. Miller explains in his article how the missionaries imposed a naturalistic orientation on the Toba in all these domains. For example, they introduced the Toba to modern agricultural techniques and a wage-earning economy which changed their relationship with the spiritual world significantly. While the Toba traditionally made their living hunting and foraging, the missionaries provided them with agricultural knowhow, seeds for sowing, and tools. This gave the Toba an increased sense of control over their own food supply, Miller argues, which left them less dependent upon their deities. Moreover, Miller explains how missionaries instilled the Protestant ethic of "he who does not work shall not eat," which replaced the traditional Toba belief that not having enough to eat was the result of an imbalance in the relationship with the spiritual world that could be restored with certain rituals (1970: 17). From then 
on, failed harvests were explained with rational reasons: bad sowing seed, too much or too little nutrients in the ground, or unfortunate weather conditions.

Miller extends his rationalization argument to the fields of education and healthcare. He shows how the mission school provided an excellent context to encourage rational thinking. He recounts how missionaries taught what they knew of physics, astronomy, and biology to the Toba and how this challenged their cosmological thinking and mythology. Phenomena that were formerly understood as animated, such as the sun or storms, were reduced to natural phenomena without any agency. Likewise, medical clinics presented the chance to spread a scientific worldview. The missionaries commonly rejected supernatural explanations for disease, such as black magic or sorcery (1970: 20). Instead, they explained, diseases were caused by natural causes; such as bacteria or a bad diet. While traditional Toba treatments were provided by a shaman who consulted his spirit helper and made use of 'power objects,' the treatments the mission clinic offered were based on western medical science. Healthcare was moved into a secular context, since penicillin or aspirin seemed to do the trick in most cases.

Miller depicts the Toba as a fairly unindividuated mass; silent objects of the mission endeavour. Indigenous evangelists or catechists, nowadays considered to have played a crucial role in mediating religious change, are not mentioned once in his analysis. Moreover, the Toba seem to have accepted the 'highly naturalistic views' of western missionaries undiscriminatingly and uncritically. Although they did not always understand the Christian teachings perfectly - Miller illustrates this with an anecdote about Toba fetishizing the Bible by placing it on the bodies of sick people for healing - Miller would have us believe that they never opposed or negotiated the mission discourse. In his analysis, all agency resides within the white, male missionary.

\section{Studies in the Footsteps of Elmer Miller}

Three years after Miller's paper, Dutch missiologist Jan van Raalte published his $\mathrm{PhD}$ thesis on the secularizing effects of the work of the Evangelische Broedergemeente (Evangelical Brother Church) in Suriname (1973). The Evangelische Broedergemeente arrived in Suriname in 1735 and continued their work there even after the church became independent in 1963. Before turning to academia, Van Raalte worked as an army pastor in Suriname from 1965 to 1970 and he witnessed rapid transformations in the country. Secularization took off after World War II but, Van Raalte holds, the foundations had been laid much earlier and Christian missionaries had played a large part in this process. 
Van Raalte's main argument resembles that of Miller; and while he does not refer to Miller in his dissertation, he includes him in his bibliography. Both point at rationalisation as the main driver of secularization, while arguing that missionaries strongly encouraged this process. Van Raalte explains that through the mission, scientific and technical thinking, industrialisation, urbanisation, and pluralization were imported in Suriname (1973: 57). Together these processes opened the gates to secularization. He also points out that Protestantism in itself is a very rational religion: its worldview is mostly disenchanted and the natural and supernatural are clearly separated (Van Raalte 1973: 71). When missionaries introduced the Protestant notion of the world to peoples with an enchanted worldview, they challenged local cosmological convictions, which instigated change. Like Miller, Van Raalte describes how missionaries propagated this naturalistic worldview in church, school, and medical clinic, unaware that this would lead to secularization (1973: 57). The word 'secular' or any of its derivatives cannot even be found in the mission reports. The first time it occurs in missionary sources is in 1947, van Raalte writes, as former missionary Van Wouw describes it as a trend directed at materialism and nihilism (1973: 112). However, earlier missionary reports have sometimes mentioned people who let go of their traditional beliefs without replacing them with other religious beliefs. For example, missionary Th. C. van Calker reported in 1859 that people in his district had stopped performing religious dances or stopped using obia (magical medicine) after he had convinced them of their futility, but added sadly that they were not interested in the Christian message (Van Raalte 1973: 171).

There are numerous other studies that present examples of rationalization and modernization in mission fields. However, besides the studies of Miller and Van Raalte, the relationship with secularization is never made explicit. Sometimes a direct link is even denied. In August 1972, a seminar was organized by the Catholic Secretariat for Non-Believers on the impact of modern civilization on religious life in Africa, and a year later a volume with the presented papers was published (Secularization in Africa, 1973). The authors argue that secularization in Africa is a direct consequence of modernization, urbanization, and modern, secular education; not of the Christian mission.

The assumption that western missionaries have been important agents of modernization is repeatedly confirmed, especially in post-colonial studies. But again, the link to secularization is generally not explicit. Anthropologists John and Jean Comaroff studied the secular aspects of the Protestant missionary project in their work on the mission in southern Africa (1991). They describe the goods and technologies that accompanied missions and show how western missionaries introduced the indigenous world to modern, western discourses. 
They discuss, for example, a dialogue between a missionary and local Tswana community members about the origin of the rain. The Tswana (an ethnic group native to Botswana and South Africa) believed specially trained priests, or rainmakers, exercised ritual power to cleanse the land, community, and atmosphere so that the rains would come. Like the Toba, the Tswana considered drought to be the result of an imbalanced relationship with ancestral spirits. The missionaries rejected this explanation and tried to provide their listeners with meteorological explanations instead. By engaging the Tswana in rational debates, they undermined traditional Tswana religious narratives (1991: 208). In addition, missionaries actively tried to demystify the magic of water by digging waterholes in the villages. While they were certainly not always successful in converting their conversation partners to their western worldviews, this did force the Tswana to critically reflect on their ideas about natural phenomena and to at least consider alternative worldviews. Comaroff and Comaroff have called this process the 'colonization of consciousness' (1991: 208-211).

In his book Christian Moderns: Freedom \& Fetish in the Mission Encounter (2007), anthropologist Webb Keane discusses the transformation and the significant role missionaries played in this process within Sumba society (Indonesia) in the late-nineteenth and twentieth centuries. A primary aim of these missionaries was to 'purify' the indigenous worldview and to liberate the Sumbese from a range of what the missionaries considered to be false beliefs and fetishisms. They argued that only once the Sumbese had adopted a more rational worldview would they be ready to become Christians. Keane explains how the missionaries especially challenged indigenous ideas about materiality by denying the agency of objects, natural phenomena, or words. Amulets, rocks, or spells did not have any power, the Dutch Protestant missionaries argued, but were simply part of the natural world which was subjected to humans by God (2007: 54). In their mission to 'emancipate' the Sumbese from superstitious beliefs and fetishisms, the Dutch missionaries challenged long-held beliefs about the world, even among those who were not interested in the Christian message. Keane concludes his study by saying, "In effect, when the missionaries attacked animal sacrifice, the worship of carvings, or magical language, they took the side of science - at times unwittingly, at others purposefully - in disenchanting some part of the world" (2007: 200).

Keane continues to explain how missionaries actively produced boundaries between the religious sphere and other societal domains in their everyday work. For example, they regularly noticed 'syncretic' expressions of Christianity in their communities. For every observed belief or practice, the missionary had to decide whether or not it transgressed the limits of what they believed was acceptable within a Christian community. Keane explains that 
the usual way of deciding whether something was acceptable was to trace its origins. Beliefs and practices that the missionaries considered to be cultural could be continued. If it had religious significance, then that belief or practice posed a danger to the Christian community and had to be altered or eliminated. Such decisions thus depended upon what these missionaries defined as religious or as cultural, which required active formation and implementation of these conceptual categories (2007: 85). And while this compartmentalization seemed helpful in deciding one's approach in facing everyday problems, it also introduced the idea that the religious sphere was confinable. Keane notices that this very process contributed to secularization in the west, yet he never explicitly claims that missionaries encouraged secularization among the Sumba (2007: 106).

Like Van Raalte, Keane suggests that sometimes missionaries were aware that challenging traditional beliefs could bring about indifferentism. He described how a missionary active among the Sumba at the end of the nineteenth century reported happily that a local maize farmer had removed Marapu statues from his fields after the missionary had pointed out their futility (2007: 234). The farmer's yield that year was not worse than that of his neighbours. He and some other villagers thus decided that offerings to the Marapu did not actually accomplish anything; and as such, became detached from their traditional beliefs. However, the missionary noticed that these lost religious beliefs were not replaced by Christian beliefs, which made him realize that it had become possible for the Sumbese to imagine a world without religious beliefs.

Many studies on Christian missions have shown that the civilization and development of indigenous communities was an important aim of mission organizations, as it was understood that converts ought to become 'cultivated Christians' (Comaroff \& Comaroff 1991; Van der Veer 1996; Elshakry 2007; White \& Daughton 2012). And, to a large extent, mission schools were remarkably successful in attracting students wishing to learn to read and write, and to learn about western technology. In some regions, like China, India, and the Middle East, mission education went far beyond merely promoting literacy. Missionaries reacted to local demands for western knowledge, and several mission schools turned into universities that offered secularized education. Examples of this include Serampore College, established in 1881 in West Bengal, or the Syrian Protestant College, now known as the American University of Beirut, which was founded by the American Board of Commissioners for Foreign Missions (ABCFM) in 1866.

The Syrian Protestant College offered classes in medicine, natural science, astronomy, and engineering, and attracted students from different ethnicities 
and religions. The institution proved successful and the number of enrolled students rose steadily, from about six hundred in 1827 to over five thousand in 1884 (Elshakry 2007: 183). In Egypt, American Presbyterian missionaries, active since 1854, opened dozens of schools, medical facilities, and public libraries, and ran rural development programs and literacy campaigns (Sharkey 2008:1). Missionary Charles Watson opened the American University of Cairo in 1920, whose curriculum included a training program for missionaries, even though the university was officially independent of the American mission (2008: 149). These institutes were successful in disseminating western scientific knowledge and values of modernity, which effectively transformed the countries in which they were established (Dujardin \& Prudhomme 2015: 288).

While these universities proved remarkably successful in terms of enrolment, the mission churches behind them made few converts and promoting Christianity through western education proved an uncertain strategy (Elshakry 2007: 214). Teachers constantly had to legitimate the work they were doing, as the mission organizations did not want to waste their limited funds on producing secularized individuals (Makdisi 2008: 191). Still, many missionaries believed modern scientific insights could help them in their work. Lynette Thistlethwayte shows, for example, how British missionaries in India used the results of western science to expose 'absurdities' in Hindu cosmology (1991). But she also describes how the tables turned and how Hindus were quick to point out inconsistencies in Christian teachings in the light of modern scientific enquiry (1991: 73-82). Likewise, in her study on the American mission in nineteenth century Syria, Marwa Elshakry discusses how more and more missionaries grew worried that people embraced modern science for their own ends and that the virtues of rational argumentation and scientific discoveries could be used just as easily against Christianity as for it (2007: 180). Whilst the founders of these institutions had believed science and rationality would pave the way to God and testify to the superiority of Protestantism, their views became increasingly contested in the age of Darwin (2007: 214).

The fact that certain mission strategies such as providing education, healthcare, and technical and agricultural know-how led to rationalization and modernization has been claimed in numerous studies. The opposite, however, has also been argued. In Birgit Meyer's study on the mission project among the Ewe in Ghana (1999), she argues that the introduction of Protestant theology in mission fields did not always lead to disenchantment. 
Missionaries of the NMG (Norddeutsche Missionsgesellschaft) arrived there in 1847 and continued their work until World War I. Although Meyer does describe them as agents of modernization, she does not connect this to rationalization, let alone secularization. In fact, she explains that the German Pietist missionaries did not simply discard the traditional worldview of the Ewe, but instead integrated those beliefs into a Christian framework. They preached that the Devil was the power behind indigenous African traditions. In other words, the existence of traditional deities, ghosts, or ancestral spirits was not denied, as missionaries among the Toba, Tswana, and Sumbese had done; instead, they were reconfigured into demons of Satan and as such continued to be important powers in daily life.

Meyer claims that this process of diabolisation was not unique to the Ghanaian context, but that it also occurred in both Protestant and Catholic mission fields around the world (1999: 110). Margaret Jolly, for example, has made similar claims for Vanuatu, an island group in the South Pacific Ocean, west of Fiji (1996). Jolly describes how Catholic missionaries of the Society of Mary, active in the Pacific since the early 1800 s, assimilated local spirits into the Catholic concept of demons (1996: 242). Yet, precisely because the missionaries tried to demonstrate the superior efficacy of the Christian God, they confirmed the agency of these ancestral supernatural powers (1996: 253). In other words, here again the enchanted worldview of the indigenous community was kept intact. Another example stems from the work of anthropologist John Peel (2000) about the Yoruba mission of the evangelical Anglican Church Missionary Society (CMS) in south-western Nigeria. Although Peel does not explicitly address diabolisation, we find a similar process happening there. For example, he presents the translations of several prayers and hymns written by indigenous Christians, and in each of them is a strong focus on the Devil and dark forces present in everyday life (2000: 292). This shows how the worldview of the Yoruba remained enchanted as old deities were not eliminated but integrated into a Christian framework.

Dutch theologian Stefan Paas has suggested that we should perhaps consider the appropriation of indigenous spiritual forces into a Christian framework as a transitional phase towards a fully disenchanted worldview. He points at the temporary upsurge in the belief in demons, witches, and other supernatural forces in Europe after the Protestant Reformation. Despite the rationalizing character of the Reformation, the belief in supernatural forces did not disappear straight away. Disenchantment, he argues, should not be regarded as a unilinear process (Paas 2019: 6-7). The Pietist missionaries in Ghana obviously hoped it would just be a matter of time before the remnants of 
indigenous religion would disappear (Meyer 1999: 138). However, recent studies on Ghanaian Christianity show that the missionaries' prayers have so far not been answered. Old gods and spirits were not only considered real forces by first generation Christians, but the belief in their power has continued to be part of the worldview of subsequent generations. This diabolised worldview continues to be present among Christians around the world today, especially in Pentecostal churches (Meyer 1999; Mohr 2013).

Like Meyer, Adam Mohr has studied the German mission endeavour in Ghana and has reached similar conclusions (2013). He holds that the German Pietist missionaries played an important part in endorsing traditional beliefs in the supernatural. Mohr explains how healing practices which were intended to deal with illnesses and immoral behavior believed to be caused by demons had emerged in Wurttemberg Pietism in the early nineteenth century (2013: 28). And although this development garnered some discussion in Germany, it strongly influenced the overseas mission. Mohr recounts how Pietist missionaries professed that malevolent forces were active in human affairs, but did not systematically teach or perform healing practices themselves. In other words, they indicated a problem, but offered no solution. Consequently an ambiguous situation arose where Ghanaian Christians, and even the missionaries, sought protection from local healers against dark forces (2013: 40).

This changed, however, towards the end of the nineteenth century, due to the developments in medical science. The missionaries became convinced that diseases were caused by natural causes and that these could be treated with medication. Slowly the missionaries began to deny the agency of spirits in human affairs, and, according to Mohr, eventually denied their existence altogether. Simultaneously, the missionaries started to reject traditional healing cures. This resulted in a crisis within the Ghanaian Christian community. The rational explanations and treatments that were offered by the missionaries were not considered sufficient, so the congregations continued to visit local healers (2013: 14). Yet church members who continued to rely on supernatural healing practices were now considered superstitious, and risked being excommunicated (2013:53).

As a consequence, more and more Christians started to leave the mainline mission churches, especially after new Protestant movements such as the Apostolic Church and pentecostalism became active in Ghana. As Birgit Meyer had already showed in her research, these churches offered a spiritual means to cope with misfortune which suited Ghanaian culture better. Mohr quotes a Ghanaian Christian who left the mission church for one of the independent churches in 1920: 
I don't know why our missionary here did not teach us the full gospel ... They never did wondrous work here as our Lord give the power to the disciples. Should you bring your Divine Healing Church out in Africa here and preach the full gospel to the people and healing the sick, many people shall believe in your Gospel than those churches who were teaching us here, because they never done miracle; they never heal the sick. (2013: 69).

The mainline churches in Ghana experienced a mass exodus from the 1950's onward. Eventually, church leaders decided that they needed to re-enchant the secularized worldview that they had been propagating by acknowledging spiritual explanations for suffering in the world, and by offering healing rituals (Mohr 2013: 82). The re-enchantment of the church and the introduction of faith healing in the Pietist framework led to a strong increase in members (2013: 92-93). Mohr concludes by saying that Protestantism in Ghana had become fully enchanted towards the end of the twentieth century and that generally Christianity in Africa today is much more enchanted than the type of Christianity that was propagated by western missionaries a century before. The spread of Protestant beliefs, modernization, and even the development of science has thus not led to disenchantment in Ghanaian society in the long run. Modernity and an enchanted worldview should therefore not be presented as being in opposition, according to Jolly, Meyer, and Mohr. While missionaries did stimulate modernization in the communities in which they were active, this did not necessarily lead to disenchantment, rationalization, or secularization. Moreover, their work shows it does not have to be one or the other; rationalization does not necessarily eliminate enchanted worldviews.

\section{In Lieu of a Conclusion}

Elmer Miller's study is a missiological exploration of Weber's thesis that Protestant Christianity brings about disenchantment and rationalization. His focus on secularization reflects contemporary trends in both Protestant theology and missiology: in 1960, theologian J. C. Hoekendijk suggested that Christianity ought to be understood as 'a secular movement' (Stanley 2018: 209). And a few years later, Dutch theologian A. T. van Leeuwen elaborated upon Weber's thesis by claiming that modern secularization is the inevitable outcome of Christianity due to its rationalizing character (Van Leeuwen 1966). In 1968, Paul Löffler edited a volume on what secularization means for missions. And secularization formed the central theme at the World Missionary 
Conferences in Mexico (1963) and Uppsala (1968) (Bosch 1991). More recent works show that secularization has remained a concern for mission organizations and that Miller's thesis continues to resonate with mission organisations and missiologists today (Paas 2019).

But while mission history has been high on the research agenda since the late 199o's, and missionaries have been increasingly considered 'agents of social change' in post-colonial studies, this review surprisingly shows that secularization has hardly been addressed in historical studies on Christian missions. Miller's paper has been republished twice in the early seventies (see bibliography), but has not been cited very frequently (less than 6o times in August 2020). And in those studies the focus is generally not on the causal relationship between Christian missions and secularization. The only other academic work I was able to find which explicitly explores this connection is the work of Jan van Raalte (1973), who researched the Dutch mission in Suriname. As previously mentioned, both Miller and Van Raalte had experience as evangelists before entering the academic world. Their findings appear to be grounded in their personal experiences in Argentina and Suriname and their texts are primarily examples of professional self-reflection, something in which the Christian missionary enterprise has always actively engaged.

That being said, there have been numerous academic studies on the Christian missionary endeavour that have taken on a similar Weberian perspective and stressed its rationalizing effects. In these works, echoes of Miller and Van Raalte's argumentation can be heard. Examples that confirm the premise that missionaries transformed people's world views and encouraged rationalization are widely available, particularly within post-colonial studies, which corresponds directly to Miller's definition of secularization. A few authors even related this process to indifferentism, as Webb Keane's anecdote about the maize farmer illustrates. But while these studies certainly didn't falsify the premise, they have not explicitly linked the rationalizing effects of the mission to secularization either. Moreover, they do not suggest their findings are replicable in other mission fields.

The central concepts in Miller's paper - modernity, rationalization, and secularization - have been questioned and unravelled since the 1970's. No longer are they perceived as universal outcomes of globalization, echoing European history. New areas of study have emerged, such as post-colonial studies, subaltern studies and gender studies, which shifted scholarly attention to resistance, negotiation, and hybridity. The focus changed to the recipients' side of the story and the various ways in which they responded to the western paternalistic civilizing mission. The effect of the rise of these fields can also be seen in mission studies, with much more having been published in recent years on 
the instrumental role local intermediaries have played in mission fields around the world (Derksen 2016), something Miller and Van Raalte have not acknowledged at all. However, the underlying assumption in these fields remains largely unchanged: the West was still perceived as the centre of modernity (Conrad 2016: 74).

More recently, the premise that modernity originated in the West has been challenged. Uniform and linear modernization theory made way for Eisenstadt's 'multiple modernities'(2000). This concept allows for a heterogenous understanding of modernity in which western patterns of modernity, characterised by disenchantment, rationalization, and secularization, are not considered the only authentic modernities. Others questioned secularization theory by pointing at the continued vitality of religion around the globe (Martin 1978; Casanova 1994; 2012; Davie 2002); and Peter Berger (1999) famously coined the concept of desecularization to signify various manifestations of the resurgence of religion in the modern world. In her research on Ghana, Birgit Meyer (1999) showed that rationalization and an enchanted worldview do not necessarily exclude each other and that enchantment can intersect with secularization. But there continue to be fervent defenders of classic secularization theory, like Steve Bruce, who argues that if other regions in the world modernize in ways similar to the European experience, we may expect the nature and status of religion to change in similar ways (2011: 201).

Lastly, attention has turned from official religion to the complexity and heterogeneity of individual religion, and from consciousness to praxis (McGuire 2008). To use modern, western notions of secularization and religiosity to study the religious lives of people in other parts of the world a century ago is challenging. To do so through the lens of missionary reports, as Miller and Van Raalte set out to do, is nearly impossible. The way concepts like 'commitment,' 'religiosity,' and 'secularization' are understood in their studies is based on contemporary normative Protestant notions. These historically bound conceptual limits, however, prevent genuine understanding of non-European religious expressions (McGuire 2008: 44). What the missionary sources, for example, identify as 'Christian,' 'religious,' or 'non-religious' could be quite different from the way indigenous populations interpreted or employed these categories to identify their personal religiosity. Perhaps some of the most valued religious practices of these people have not been identified as 'religious' by western missionaries. To conclude, based on the available academic literature on the global Christian mission endeavour in the nineteenth- and early-twentieth century, it is not possible to provide a clear-cut answer to the research question of this review or to determine universal long-term effects of the Protestant mission, because the topic has not been explored sufficiently in the past fifty years. 


\section{References Cited}

Bender, Courtney and Taves, Ann, eds. (2002). What Matters? Ethnographies of Value in a Not So Secular Age. New York: Columbia University Press.

Berger, Peter, ed. (1999). The Desecularization of the World. Resurgent Religion and World Politics. Washington: Wm. B. Eerdmans Publishing Co.

Berger, Peter (2012). "Further Thoughts on Religion and Modernity." Society 49, 4:313-316.

Bilgrami, Akeel (2012). "What is Enchantment?" In Michael Warner, Jonathan VanAntwerpen and Craig Calhoun, eds. Varieties of Secularism in a Secular Age. Cambridge, Harvard University Press: $145^{-165}$.

Bosch, David J. (1991) Transforming Mission. Paradigm Shifts in Theology of Mission. New York: Orbis Books.

Bruce, Steve (2011). Secularization. In Defence of an Unfashionable Theory. Oxford: Oxford University Press.

Buckser, Andrew and Stephen D. Glazier (2003). The Anthropology of Religious Conversion. Oxford: Rowman and Littlefield Publishers.

Casanova, José (1994). Public Religions in the Modern World. Chicago: The University of Chicago Press.

Casanova, José (2007). "Rethinking Secularization: A Global Comparative Perspective." In Peter Beyer and Lori Beaman, eds. Religion, Globalization and Culture. Leiden: Brill.

Casanova, José (2012). “A Secular Age: Dawn or Twilight?” In Michael Warner, Jonathan VanAntwerpen, and Craig Calhoun, eds. Varieties of Secularism in a Secular Age. Cambridge, Harvard University Press: $265^{-281}$.

Comaroff, Jean and John Comaroff (1991). Of Revelation and Revolution: Christianity, Colonialism and Consciousness in South Africa, vol 1. Chicago: The University of Chicago Press.

Conrad, Sebastian (2016). What is Global History? Princeton: Princeton University Press.

Davie, Grace (2002). Europe: The Exceptional Case. Parameters of Faith in the Modern World. London, Darton, Logman, and Todd Ltd.

Derksen, Maaike (2016). "Local Intermediaries? The Missionizing and Governing of Colonial Subjects in South Dutch New Guinea, 1920-42." The Journal of Pacific History 51, 2:111-142.

Dujardin, Carine and Claude Prudhomme, eds. (2015). Mission and Science, Missiology Revisited, 1850-1940. Leuven: Leuven University Press.

Eisenstadt, S. (2000). "Multiple Modernities." Daedalus 129, 1:1-29.

Elshakry, Marwa (2007). "The Gospel of Science and American Evangelism in late Ottoman Beirut." Past and Present 196, 173-214. 
Ertit, Volkan (2018). "Secularization: The Decline of the Supernatural Realm." Religions 9, 92:1-18.

Etherington, Norman (2005). "Education and Medicine." In Norman Etherington, ed. Missions and Empire. Oxford: Oxford University Press: 261-284.

Gunson, Neil (1994). "British Missionaries and their Contribution to Science in the Pacific Islands." In Roy MacLeod and Philip F. Rehbock, eds. Darwin's Laboratory: Evolutionary Theory and Natural History in the Pacific. Honolulu: University of Hawaii Press, 283-316.

Griffiths, Gareth (2008). “Trained to Tell the Truth': Missionaries, Converts, and Narration." In Norman Etherington, ed. Missions and Empire. Oxford: Oxford University Press, $153-72$.

Hefner, Robert W. (1993). Conversion to Christianity: Historical and Anthropological Perspectives on a Great Transformation. Berkeley: University of California Press.

Herbert, David (2004). Religion and Civil Society: Rethinking Public Religion in the Contemporary World. London and New York: Routledge.

Hovland, Ingie (2013). Mission Station Christianity: Norwegian Missionaries in Colonial Natal and Zululand, Southern Africa 1850-189o. Leiden and Boston: Brill.

Jolly, Margaret (1996). "Devils, Holy Spirits, and the Swollen God: Translation, Conversion and Colonial Power in the Maist Mission, Vanuatu, 1887-1934." In Peter van der Veer, ed. Conversion to Modernities: The Globalization of Christianity. New York: Routledge, 231-262.

Keane, Webb (2007). Christian Moderns, Freedom \& Fetish in the Mission Encounter. Berkeley and Los Angeles: University of California Press.

Kruithof, Maryse (2017). "Localising Christianity, Negotiating Borders in Transnational Space." Social Sciences and Missions 30 (1-2). Leiden: Brill: 9-29.

Leest, Charlotte van der (2008). "Conversion and Conflict in Palestine: The Missions of he Church Missionary Society and the Protestant Bishop Samuel Gobat." PhD diss., University of Leiden.

Leeuwen, Arend Th. Van (1966). Het christendom in de wereldgeschiedenis. Amsterdam: Ten Have. Originally published as Christianity in World History. New York: Scribner's (1964).

Li, Ji. (2012). "Measuring Catholic Faith in Nineteenth- and Early Twentieth-Century Northeast China." In O. White and J. P. Daughton, eds. In God's Empire: French Missionaries and the Modern World. Oxford: Oxford University Press.

Löffler, Paul, ed.(1968). Secular Man and Christian Mission. London: SCM Press.

Makdisi, Ussama (2008). Artillery of Heaven: American Missionaries and the Failed Conversion of the Middle East. New York: Cornell University Press.

Martin, David (1978). A General Theory of Secularization. Oxford: Basil Blackwell.

Martin, David (2005). On Secularization: Towards a Revised General Theory. Farnham: Ashgate. 
McGuire, Meredith (2008). Lived Religion. Faith and Practice in Everyday Life. Oxford: Oxford university Press.

Meyer, Birgit (1999). Translating the Devil: Religion and Modernity Among the Ewe in Ghana. Edinburgh: Edinburgh University Press.

Miller, Elmer S. (1970). "The Christian Missionary, Agent of Secularization." Anthropological Quarterly 43, 1:14-22. Reprinted in: Missiology, An International Review (1973) (1): 99-107. Reprinted in Patricia Lyon, ed. (1974). Native South Americans, Ethnology of the Least Known Continent. Waveland Press: 391-396.

Mohr, Adam (2013). Enchanted Calvinism, Rochester: University of Rochester Press.

Morrison, Hugh (2013). "Theorising Missionary Education: the Bolivian Indian Mission," 1908-1920. History of Education Review 42, 1:4-23.

Oosthuizen. G. C. (1968). Post-Christianity in Africa: A Theological and Anthropological Study. London: Hurst.

Paas, Stefan (2019). “'Notoriously Religious' or Secularising? Revival and Secularisation in Sub-Sahara Africa." Exchange 48, 1:26-50.

Peel, John (2000). Religious Encounter and the Making of the Yoruba. Bloomington: Indiana University Press.

Secretariatus pro non credentibus (1973). Sécularisation en Afrique? / Secularisation in Africa. Rome.

Shah, Rebecca Samuel and Carpenter, Joel (2018). Christianity in India: Conversion, Community Development, and Religious Freedom. Minneapolis: Fortress Press.

Sharkey, Heather (2008). American Evangelicals in Egypt. Princeton: Princeton University Press.

Skeie, Karina Hestad (2013). Building God's Kingdom: Norwegian Missionaries in Highland Madagascar 1866-1903. Leiden: Brill.

Stanley, Brian. (2018). Christianity in the Twentieth Century: A World History. Princeton. Princeton University Press.

Taylor, Charles (2007). A Secular Age. Cambridge. Harvard University Press.

Taylor, Charles (2012). "Afterword: Apologia pro libro suo." In Michael Warner, Jonathan VanAntwerpen, and Craig Calhoun, eds. Varieties of Secularism in a Secular Age. Cambridge, Harvard University Press: 300-321.

Thistlethwayte, Lynette (1991). "The Role of Science in the Hindu-Christian Encounter." In Geoffrey a Oddie, ed. Religious Traditions in South Asia: Interaction and Change. London: Curzon Press: 81-9o.

Tschannen, O. (1991). "The Secularization Paradigm: A Systematization." Journal for the Scientific Study of Religion 30: 395-415.

Van Raalte, Jan (1973). Secularisatie en zending in Suriname. Wageningen: H. Veenman en Zonen B. V.

Veer, Peter van der, ed. (1996). Conversion to Modernities: The Globalization of Christianity. New York: Routledge. 
Vorster, Nico (2013). "Christianity and Secularization in South Africa: Probing the Possible Link Between Modernization and Secularization." Studies in World Christianity 19, 2:141-161.

Warner, Michael, Jonathan VanAntwerpen, and Craig Calhoun, eds. (2010). Varieties of Secularism in a Secular Age. Cambridge: Harvard University Press.

Weber, Max (1922, 1978). Economy and Society: An Outline of Interpretive Sociology. Berkley, University of California Press.

White, O. and Daughton, J. P. (2012). In God's Empire: French Missionaries and the Modern World. Oxford: Oxford University Press.

\section{摘要}

有人提出, 基督教由于强调洁净化和理性化, 与世俗化有着千丝万缕的联系。但 是, 如果我们相信欧洲的世俗化至少部分是由于基督教内部的发展, 那么我们可以 假设, 基督教宣教士成功的地方就会出现世俗化吗? 基督教宣教在不知不觉中在其 使命领域煽动了世俗化吗? 本文献综述分析了美国人类学家埃尔默. 米勒在《基督教 宣教士, 世俗化代理人》（1970 年）一文中提出的论点, 并探讨了他的论文在过去 五十年中是否在学术文献中得到证实。米勒将理性化作为世俗化的主要驱动力, 并 解释了宣教士是如何在这一进程中发挥决定性作用的。本文表明, 虽然理性化经常 在其他文献里被提及为基督教宣教带来影响, 但这个过程很少与宣教工场的世俗化 挂上钩。

\section{Resumen}

Se ha sugerido que el cristianismo está estrechamente vinculado con la secularización debido a su énfasis en la purificación y la racionalización. Pero si creemos que la secularización en Europa ha sido en parte causada por acontecimientos internos dentro del cristianismo, ¿podemos suponer entonces que la secularización surge en cualquier lugar donde los misioneros cristianos son exitosos? La misión cristiana, ¿ha promovido sin querer la secularización en los campos misioneros? Esta revisión bibliográfica analiza el argumento que el antropólogo estadounidense Elmer Miller hizo en el artículo "El misionero cristiano, un agente de la secularización" (1970) e investiga si su tesis ha sido comprobada en la literatura académica de los últimos cincuenta años. Miller presenta a la racionalización como el principal motor de la secularización y explica cómo los misioneros han desempeñado un papel decisivo en este proceso. Este trabajo demuestra que, si bien la racionalización a menudo se ha mencionado en otras fuentes como un efecto de la misión cristiana, el proceso raramente se ha relacionado con la secularización en el campo misionero. 